\title{
The "imaginary world" of nationalistic ethics: Feasibility constraints on Nordic deportation corridors targeting unaccompanied Afghan minors
}

\section{Martin Lemberg-Pedersen}

Department of Culture and Global Studies, Aalborg University, lemberg@cgs.aau.dk

DOI: http://dx.doi.org/10.5324/eip.v12i2.2425

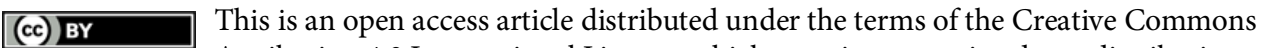
Attribution 4.0 International License, which permits unrestricted use, distribution, and reproduction in any medium, provided the original author and source are credited.

This article examines Swedish, Danish and Norwegian governments' participation in the European Return Platform for Unaccompanied Minors (ERPUM) project and its failed attempts to deport unaccompanied minors (UAMs) to Afghanistan. It argues that ERPUM is an interesting and urgent case of a "deportation corridor" and suggests that this framework can benefit from analysis through normative and applied ethics and in particular discussions of feasibility constraints. It therefore identifies and critically assesses two nationalistic arguments for deportation common in Nordic politics, based on appeals to credibility and humanitarianism. Considering the growth of nationalistic immigration policies in Nordic states, the article turns the usual discussion of feasibility on its head by showing that not only cosmopolitan, but also nationalistic ethics must face up to charges of lacking realism. More specifically, it argues that the case of ERPUM illustrates how nationalistic deportation ethics may rely on inconsistent normative and erroneous empirical assumptions, which can be criticized for their arbitrariness, ideological grounding and lack of feasibility.

Keywords: deportation corridors, ERPUM, immigration ethics, feasibility, unaccompanied minors, Afghanistan

\section{Introduction}

In recent years, European countries have accelerated deportations to Afghanistan, for instance by the EU-Afghanistan Joint Way Forward-agreement (JWF 2016) that aims to deport at least 80000 rejected Afghan asylum seekers. Several European countries, including Denmark, Finland, Sweden and Norway, have conducted deportations of adults to Afghanistan. In 2016, Norway was the European country with the highest number of forced returns. Between January and November 2016, Norway forcibly returned 278 Afghans, according to a Norwegian embassy attaché in Kabul (New York Times, 12.11.2016).

In the context of a "deportation turn" in Western asylum politics (Gibney 2008), the article applies the concept of "deportation corridor" (Drotbohm and Hasselberg 
2015: 553) to Nordic attempts to deport unaccompanied minors to Afghanistan. Swedish, Danish and Norwegian involvement in the 2011-2014 EU Commissionfunded project, ERPUM (European Return Platform for Unaccompanied Minors), is used as a case study.

Focusing on the concrete processes of a deportation corridor, the article applies the notion of "feasibility constraints" and examines some arguments offered for Nordic deportation politics in general and ERPUM in particular. This turns on its head the usual manner in which the realism and idealism of asylum policies are discussed both in immigration ethics and political debates. Rather than asking about the feasibility of demanding cosmopolitan ethics, like open borders, the article directs our attention to the under-examined question of nationalistic ethics' lacking feasibility.

For simplicity, this article uses the legal category of "unaccompanied minors" (UAMs), but it must be noted that this categorization is contested and ambiguous. Age assessments are widely challenged as arbitrary (cf. Noll 2016), and they also create contradictions in the children's' self-narration between the systemic age ascription based on statistical models and chronology, and a relational age-ascription based on their family relations (cf. Martinez 2017). It has also been pointed out that the challenges of lacking a social network and the vulnerability facing deportable youth are sometimes even heightened by the transition into adulthood, as "aged-out minors" no longer fall under states' obligations under the Convention of the Rights of the Child (CRC) (Chase, Allsopp and Mitchell 2014).

The following section outlines how the case study of ERPUM contributes to the Nordic literature on UAMs and deportation studies in general. The article then identifies a gap in the immigration ethics literature, namely how nationalistic deportation ideals have not been problematized in terms of their lacking feasibility in the real world. Next, two arguments for deportation are introduced, those of credibility and humanitarianism. These are principled nationalistic justifications, but they also feature in current Nordic discourses on the politics and bureaucracy of deportations. Noting that the liberal nationalistic ethics of David Miller do not engage with deportations or unaccompanied minors, the article nevertheless argues that such ethical views operate with (underexplored) assumptions about the feasibility of deportation politics. Accordingly, the discourses surrounding ERPUM are examined in order to critically assess the strengths and weaknesses of the arguments, with a particular focus on the underlying assumptions about the feasibility constraints they rely on.

I now turn to situate ERPUM as a deportation corridor within the field of deportation studies.

\section{The ERPUM project as a "deportation corridor"}

Studies of Nordic states' deportation infrastructures are dominated by governmentcommissioned reports that assess the potential for assisted returns and deportations (cf. Danielsen and Seeberg 2006; Borhan et. al 2011; Lidén et al. 2013; ERPUM 2014). Some critical work is however emerging (see DeBono 2017; Plambech 2017), and by examining the attempted deportation corridor of ERPUM, this article further links Nordic literature on children in asylum systems with the field of "deportation studies" (Coutin 2015). 
This emergent field offers many perspectives on deportation, ranging from genealogies of expulsion (Walters, 2002; Kanstroom, 2007); the relation between deportation and citizenship (Anderson, Gibney and Emanuela Paoletti, 2011); how immigration law produces "illegalities" and "deportability" (De Genova, 2002; De Genova and Peutz, 2010); the geopolitics and infrastructures underpinning deportation (Cassarino, 2014; Collyer, 2012); and what happens after deportation (cf. Schuster and Majidi 2015; Khosravi 2018). However, save for a few examples dealing with European policies, the international literature has not engaged with UAMdeportations specifically (Fekete 2005, 2011; Lemberg-Pedersen 2015).

For this reason, the article suggests "deportation corridors" (Drotbohm and Hasselberg 2014) as a useful analytical framework to combine these focus areas. It denotes how deportation politics are composed of dynamic and transnational processes and infrastructures; how these politics are continuously shaped through diplomacy and geopolitics; and how they have psychosocial and spatiotemporal consequences for potential deportees as well as for the communities that persons are deported from and to (Drotbohm and Hasselberg 2014; cf. Peutz 2006).

ERPUM was the first EU project with the ambition to organize the administrative deportation of UAMs, and its ambitions have since then been transferred to the EUAfghanistan Joint Way Forward agreement (JWF 2016). By 2018, Nordic countries were key actors in the construction of ERPUM: Sweden coordinated the project, Denmark helped develop it, and Norwegian policies were used as a pilot model. The remaining participants were the United Kingdom, the Netherlands and Belgium. ERPUM planned for deportation corridors to Iraq, Morocco and Afghanistan, eventually singling out the latter. The EU Commission funded ERPUM's first phase from January 2011 (€692 775), and its second phase from December 2012 (€596 356). Amidst a resurgence of violence and bombings in Afghanistan, the project was discontinued in June 2014, without deporting a single UAM (Lemberg-Pedersen and Chatty 2015). ERPUM is therefore also an instructive case of a deportation corridor, because it failed. However, despite this, it also facilitated legal reforms aligned with the 2008 EU Returns Directive's Article 10.2, in Norway (2009), Denmark (2010) and Sweden (2012).

The notion of a deportation corridor is useful for analyzing ERPUM, as it expands our gaze beyond the actual event of return. It highlights how return relies on transnational and multilocal practices, varied geographies, and different actors and institutions (Drotbohm and Hasselberg 2015). It also covers the many experiences of deportation, from UAMs living in fear of deportation to events preceding and following the return, such as arrest, detention, return and existence thereafter. The deportation corridor analytics also encompass political economy and the infrastructures underpinning the policy, including the governments and national and international organizations and institutions involved (cf. Walters 2017).

Grounded in Northern European civil servant networks striving for deportation corridors to Afghanistan, ERPUM combined five main components: asylum rejection - family tracing - deportation procedures - reception facilities - reintegration (ERPUM 2014; Lemberg-Pedersen 2015). For reasons of scope, this article focuses mostly on only the first three components, although all are mired in controversy. 


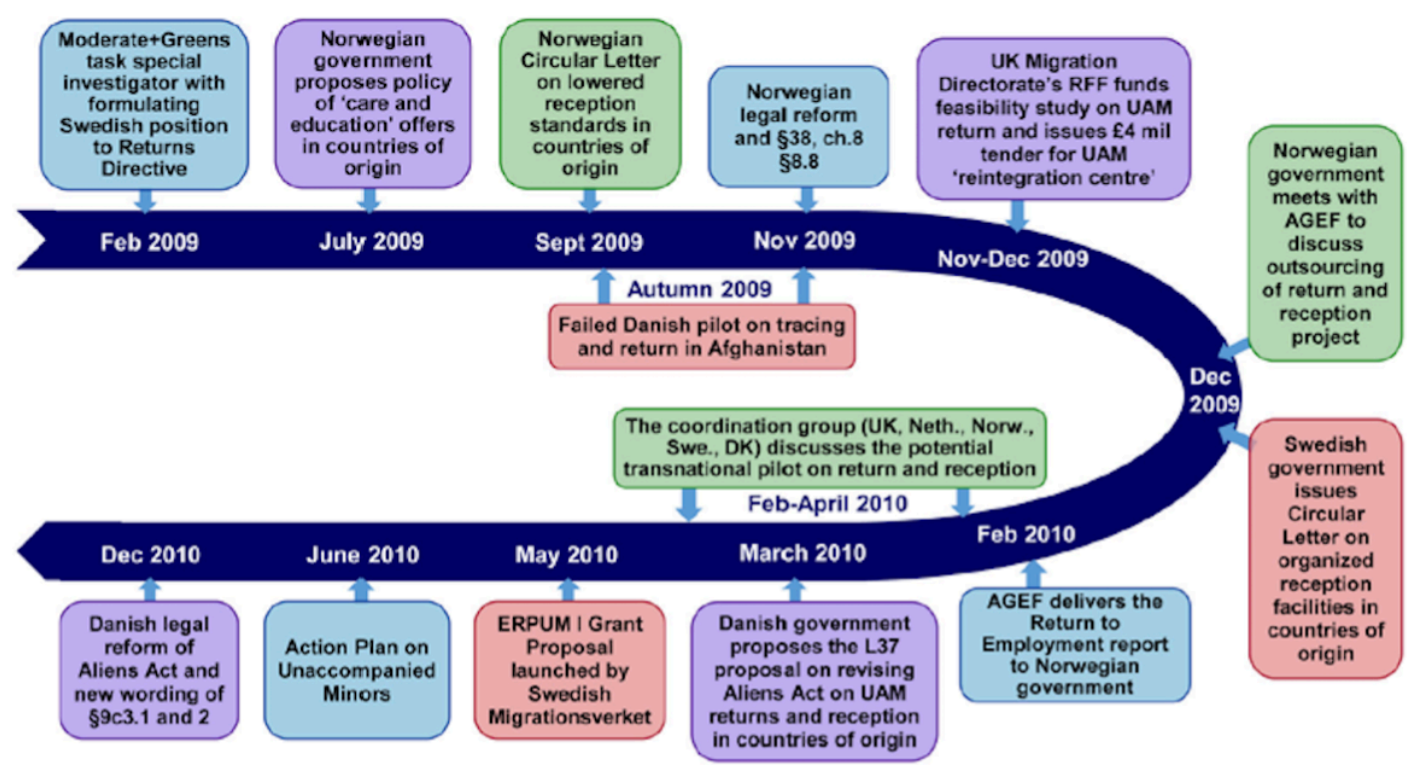

Figure 1: Key developments in the preparation for the ERPUM-deportation corridor 2009-2010 (Lemberg-Pedersen 2015)

The project's idea of deportation orphanages in Afghanistan met with fierce criticism from the press and civil society actors. Save the Children Norway (2012) called it "experimenting with children's lives," and the Children's Council and Save the Children submitted 25 critical questions to the Danish Minister of Justice Morten Bødskov (Børnerådet \& Red Barnet 2012). An official from the Afghan Ministry of Refugees and Repatriation (MoRR) was also extremely critical, saying, "We don't support the repatriation of children because a lot of them left at an early age so we are not sure we can find their parents or relatives[...] They could fall into the hands of drug addicts, Taliban or criminal gangs.” (BBC Online 24 November 2011).

The participating governments offered quite different perspectives on the kind of corridor they were pursuing, illustrating the corridor's complexity. At some points, ERPUM officers argued that children could be forcibly returned, only to later reverse that statement. And while Belgian authorities provided public assurances against forced UAM-returns, instructions to the Swedish police and statements by Danish, Dutch, and Norwegian officials seemed to condone forceful deportations. At the end of the day, ERPUM was not the unifying platform its own discourses made it out to be. Instead, the participating countries seemed to use it to promote their national priorities. It is therefore more accurate to say that the supranational ERPUM pilot actually facilitated the multiplication of several distinct national deportation corridors. In the following, the focus is turned to the normative dimension of Nordic UAM-deportation corridors.

\section{Normative questions concerning feasibility in nationalistic ethics}

Deportation studies are still dominated by certain disciplines, and wanting for the potential contributions of others. One of these is immigration ethics, emerging in the 1980s and 1990s with the central principled debate between the impartial and 
cosmopolitan valuation of universal rights and the national-cultural valuation of particular societies (cf. Brown and Shue 1981; Walzer 1983; Beitz 1983; Carens 1987; Barry and Goodin 1992; Miller 1995). However, states' enforcement of policies, including deportation politics, has remained a gap, also in relation to the plight of migrant children (cf. Sager 2017). Moreover, applied ethical analyses of Nordic asylum policies are lacking (see though Lemberg-Pedersen 2011; Svendsen 2012; Josefsson 2017), and few have ventured into deportation ethics (but see Cohen 1997; Gibney and Hansen 2003; Gibney 2008, 2013, 2015; Lenard 2015).

This article applies ethical analysis to Nordic UAM-deportations through the notion of "feasibility constraints". This is when facts are invoked to constrain a prescriptive conclusion, because they are seen as limiting the feasibility of courses of action otherwise recommended by a normative principle (Lægaard 2016: 13). The focus on feasibility follows the ambition of navigating "realistic utopias" between principled discussions of ideal theory and the challenge of non-ideal theory regarding partial compliance to principles in actual contexts (Rawls 1999). It reflects the idea that while any kind of justice relies on separating what is the case from what ought to be the case, justice is also constrained by the idea that 'ought' implies 'can' (Islar et al. 2017; Wiens 2014).

The question concerning feasibility revolves around the likelihood of implementing ideals and has received more attention from immigration ethics recently (Carens 1999, 2013; Pevnik 2011; Miller 2013; 2016; Bosniak 2017). Matthew Gibney (2004: 196) has pointed out that in ideal theory, the desirability of moral principles is often discussed independently of questions of agency. This approach is problematic as it leaves the question of implementation underdetermined. More precision is required to address the practical constraints faced by governments when they try to realize certain normative ideals through their policies. Gibney (2004) distinguishes between structural/institutional, political and ethical constraints.

The first group of constraints encompasses limitations that are inimical to the function of states, such as the member/non-member-distinction, and poses certain constraints on what can be required from them. Gibney argues that the moral value of an ideal should not rely on a will to implement it, since ideal theory may also demand that states create radical new institutions capable of implementing more demanding ideals. The second group - the political constraints - have to do with factors like refugee determination processes, domestic political environment, including nationalist movements, job scarcity, housing policies, crime, and relations with other states. The third group - the ethical constraints - revolve around the implications of trying to implement certain ideals, for instance if an unintended side effect of their implementation is that general support for them erodes.

Ethical discussions about feasibility often focus on agency and motivational power, linking this to the principled debate between cosmopolitans and nationalists, and the derived clash between proponents of open and closed borders (cf. Carens 1987; Abizadeh 2008; Miller 2010; Holtug 2011). The ethical nationalist David Miller also talks of feasibility constraints (cf. 2013), and despite at times labeling his view "liberal nationalism" (Miller 1995), he disagrees with Gibney about the balance between universal liberal ideals and motivation. He says that the social relations of the real world impose "feasibility constraints on the principles that can justifiably be advanced," and that the reasons for accepting principles must come from "beliefs that people hold to begin with... rather than some imaginary world whose natural and 
social laws are different from our own." (Miller 2013: 4). This illustrates a general tendency with proponents of border controls, who depict themselves as realists rooted in the non-ideal world, while framing those arguing for universal ideals, including the rights of deportees, as disconnected from the actual motivations of people (cf. Miller 2007; Carens 2013; Gibney 2004).

However, this framing is misleading. The global proliferation of anti-deportation campaigns and historical and current formations of institutions promoting equal and fundamental rights illustrate that cosmopolitan idealism also carries motivational power.

Yet, the political pushbacks against such ideals should not be seen, as some have argued, as "a swan song to a vanishing ideology of nationhood" (Benhabib 2006: 65). Rather, nationalistic ideology and the associated understanding of feasibility in immigration ethics are on the rise. A stark example of this arose when the majority whip of the Danish Social Democratic opposition party, Henrik Sass Larsen, charged that:

The utopian humanist idea of free immigration and global rights for refugees has led to a mass immigration that the Western countries' economies and political and social structures cannot bear...People do not want to cancel the nation-state in favor of a Utopia. They like their state, their country, their language, their national identity...the era of the humanistic Utopia is over...The collapse is already underway, and the only reason why the humanist shouts are so loud is that they dominate the state media." (Information 1.4.2017, author's translation).

The figure of the "utopian humanist", who from his/her ideals espouses free immigration to the ruin of his/her own society, is similar to the kind of cosmopolitanism that David Miller criticizes with his ethical nationalism (cf. 1995, 2005). However, as Sune Lægaard (2010) has remarked, it is "theoretically unsatisfactory and normatively implausible" when standard debates in immigration ethics end up with such stark dichotomies. One way of understanding this stalemate is to recognize its link to ideological battles. And without equating the stark comments of nationalistic politicians like Sass Larsen with the more nuanced liberal nationalism of Miller, an exploration of the latter's arguments about feasibility and nationalistic ethics may assist us with this task.

For Miller, the feasibility of ideals is derived from their ability to motivate individual action among ordinary citizens, something that he, like Sass Larsen, assumes cosmopolitanism to be incapable of. This means that the feasibility constraint is translated into a requirement that a moral theory should exhibit a close fit with pre-theoretical everyday judgments (Miller 2002: 6; Miller 2013: 34), referred to as motivational power being generated from within social circumstances. According to Miller, cosmopolitans commit the fallacy of "fact-independent theorizing" by implementing basic principles regardless of ordinary citizens' social contexts (cf. Miller 1995: 5). He claims that normative theory must be developed out of and made to fit particular political settings (Miller 2016: 17; 2013: 45). This is related to Rawls' conception of feasibility, as the stable implementation of principles over time that relies upon their connection to general facts about the human condition, including psychology (Rawls 1971: 158-61). At the meta-ethical level, then, Rawls and Miller hold that principles are fact-dependent, free from external "master 
principles" and generated from within particular contexts, such as national cultures (Miller 2002: 10).

Cases certainly exist where cosmopolitan immigration ethics seem abstract and pressed in providing concrete guidelines. One example is the liberal dilemma of implementing free movement in contexts where states face secondary refugee movement following relocation and resettlement. Another is the question of whether states can ever be allowed to refuse protection to a person, if they have already admitted another person from circumstances of identical moral relevance. Some cosmopolitans have themselves acknowledged these difficulties with liberal theory. Carens (1999: 1082) has argued that they are caused by the exclusionary practices of self-professed liberal democratic states, while Cole (2000: 198) points to postcolonial problems with the roles of reason and universalism residing at the heart of liberal theory. However, it is not clear why nationalists should think they fare better than cosmopolitans with such hard cases, since nationalistic ethics is also in the business of arguing from principled values. Miller criticizes ideal theory, but it can be argued that his contextualism simply replaces an external master principle with an internal one from within political communities. ${ }^{1}$

Even if Miller does not himself engage with the question of deportation and unaccompanied minors, the generative role he claims to grant facts illustrates the fundamental role that feasibility claims occupies for nationalistic ethics and politics. However, the relationship between nationalistic ideals and facts in deportation politics is more problematic than Miller assumes. The next section therefore unfolds a deeper inquiry into the relationships between different kinds of facts and two nationalistic justifications for the implementation of deportation corridors.

\section{Two arguments for deportations The credibility argument}

One argument for deportation corresponds to widely shared intuitions about the principled legitimacy and credibility of asylum systems, namely their ability to differentiate between those who are granted protection and those who are not (Gibney 2008) (hereafter, the credibility argument). If people are not granted protection, they must leave, and if they do not leave, the very idea of having a system that grants states the discretion to distinguish between legitimate and illegitimate claimants in the first place becomes pointless. Therefore, deportation corridors are necessary to preserve a credible asylum system. This principled argumentation is common in Nordic politics and was invoked when the Social Democratic Secretary of State in Norway, Pål Lønseth, presented his government's new deportation strategy for 2011-2016, saying, "We must give a clear signal that asylum is meant for people with protection needs. If you don't have the right to protection, you must count on being deported..." (Vårt Land, April 11, 2012). A similar argumentation was found in the Government Platform document (2016) of the Danish Løkke-government. Under the label of a "balanced and realistic" immigration policy, it stated that "many rejected asylum seekers refuse to leave voluntarily and stay in the country. That undermines the legitimacy of the asylum system. That is why the government wants to strengthen the collaboration and dialogue with home countries about readmission of their own nationals..." 
Moving from this principled point, we can apply the credibility argument to a concrete claim about Nordic asylum systems, namely that the inability to deport people leads to institutional backlogs. This variant can be called the cost claim, which claims that institutional backlogs of undeportable migrants force authorities to reallocate resources from other asylum claimants, as well as from legitimate refugees. This then constitutes a structural constraint, which allows states to override undeportables' rights and dignity and place them in deportation corridors.

Another variant of the credibility argument is the claim of racist backlash (Gibney 2004: 212), in which state resources spent on undeportables leads to distrust and opposition to the very idea of an asylum system offering protection among voter segments in the receiving country. To avoid sacrificing the asylum system, the argument goes, states must be able to deport. This variant of the argument poses a political constraint on the rights of undeportables, perceived to arise when governments try to implement the ideal of protection, while also attempting to avoid feeding a backlash from racist voters unwilling to offer protection to refugees. The argumentation also links to nationalist-populist narratives of "asylum shoppers" and "abusers."

The credibility argument thus finds its intuitive force in structural and political constraints, which make implementing the ideal of refugee determination lengthy and costly. This might be thought to furnish governments "with a powerful argument to dampen criticism from those concerned with human rights" during deportations (c.f. Gibney 2008: 22). Yet, the argument faces serious objections, but before considering these, we must first turn to the second argument for Nordic deportation corridors.

\section{The humanitarian argument}

This argument invokes humanitarian justifications for deportations by putting forward structural, political and ethical constraints on the ideal that UAMs should be granted independent agency. The core claim is that swift deportations, even if forced, are the most humane option for rejected asylum seeking UAMs (hereafter the humanitarian argument). This illustrates how authorities vacillate between arguments of care and control (Walters 2011; Pallister-Wilkins 2015; LembergPedersen 2018).

Arguments about the humanity of UAM deportations come in several variants. One can be called the child rights variant. In its later stages, ERPUM (2014: 14) repeatedly argued that common-European collaboration on the quick and ordered return of UAMs to Afghanistan "promotes child rights dialogues in the EU" and even framed ERPUM as "a vital pillar for the protection of minors." UAM deportations, it was claimed, avoid having children placed in the psychological limbo of camp life found to have devastating psychosocial consequences, such as restlessness, despair, fatigue, self-harm, mental breakdowns and desubjectification (Vitus 2010; Seglem, Oppedal and Raeder 2011; Lier, Jansson and Rich 2011; Montgomery 2011). Consequently, says the humanitarian argument, there are ethical side effects to implementing the ideal that UAMs can choose to reject deportation. If the ideal is to preserve UAMs' rights and integrity, the psychosocial risks of camp life generate constraints so severe that the ideal becomes infeasible.

A second and related variant of the humanitarian argument also dominated the later stages of ERPUM. This we can call the family unity variant, namely that family 
tracing is a "key element to ensure family reunification and unity." According to this line of argumentation, family tracing efforts solve the tragic situation of "broken and lost ties with the family and other relatives," which is "a major cause of emotional ailment" among UAMs in Nordic asylum systems (ERPUM 2014: 20). Recent research discusses how these two variants of the humanitarian argument also feature in the Swedish Migration Court of Appeal's interpretation of the best interest of the child and are used to justify not only the right to stay, but sometimes also child deportations (Josefsson 2016).

A third variant of the humanitarian argument occurred in ERPUM's early stage (2010: 13). It claims that swift deportations will make children realize the futility of a journey to the Nordic countries, so that "those minors who are not in need of protection will not make the long and risky journey to Europe since the risk of being returned is higher." We can call this the benevolent deterrence variant. This variant is common in Nordic deportation discourses and is sometimes also linked to the argument of credibility. This was illustrated in 2010, when Norwegian Social Democratic prime minister Jens Stoltenberg justified the 2011-2016 deportation strategy, arguing that "[s]wift returns will preempt the need for persons without protection needs to come to Norway, and that has great significance for the legitimacy of the institutions of asylum." (VG Nyheter 10.5.2010). This argumentation is connected to debates during the 2000s among Norwegian and Swedish media and politicians concerning the multiple representations of UAMs as vulnerable children, strategizing migrants and independent rights holders (Stretmo 2014).

These three variants of the humanitarian arguments all appeal to strong ethical ideals in their justifications, but each of them also faces problems. Before discussing these, we will first return to the credibility argument.

\section{Feasibility constraints on nationalistic deportation ethics Reassessing the credibility argument for deportation}

One problem with the credibility argument is that it assumes states' asylum decisions to be fair. However, critics say that this assumption is problematized by states' actual refugee determination practices. We may agree in principle that for protection systems to function, applicants must accept final decisions. But we may also hold that because authorities' decisions can be arbitrary and immoral and are often reversed after media or grassroots pressure, it may be morally legitimate to refuse particular deportation decisions (Sager 2017; see also Johannesson, 2017; Wettergren and Wikström 2013). Even if this undermines the ideal of a differentiating protection system, the imperfect implementation of that ideal can create gross injustices that need to be rectified.

What we can call the charge of arbitrariness is compatible with accepting that liberal democratic states have discretion over their own borders (cf. Gibney 2008: 153; Lenard 2015: 465). Deriving from neo-Republican ideals, this concept ventures that bureaucratic discretion is morally wrong when it is arbitrary and lacks legal democratic checks and balances that would allow those affected to contest and reshape it according to an ideal of nondomination (cf. Larmore 2003). Deportation corridors can be criticized for unfair domination, but arbitrariness may also be caused by a lack of time, rises in numbers or inadequate funds. Either way, the charge points 
out that such factors constitute political, structural and ethical constraints on the ideal assumed by Nordic politicians of a differentiating and deporting system of protection.

Consider, for instance, the massive differences between Northern European states' recognition rates for Afghan asylum seekers. Between January and June 2015, the EUwide recognition rate for Afghan asylum seekers was $68.2 \%$, but in Denmark it was 34.7\% and 69.7\% in Germany, 76.6\% in Sweden and 83.6\% in Norway (Refugees.dk website). Since Denmark, Germany, Sweden and Norway all work from the 1951 Refugee Convention and its 1967 Protocol, these huge differences illustrate arbitrariness not only in asylum but also in deportation decisions, because national authorities' low recognition rate of asylum seekers leads to deportation procedures.

A tragic Danish example of arbitrariness occurred in the fall of 2015 when Danish authorities enforced a return decision to Afghanistan of the brothers Vahid and Abolfazi Vazari. They had voiced fears on national TV that their lives would be in danger if they were returned. The Danish authorities departed from institutional guidelines and assigned the older brother as the legal guardian of his minor brother. When the former reached adulthood, Danish authorities effectuated the deportation of them both, arguing that the older brother could now function as the adult guardian of the younger brother after the deportation, and that the two brothers could consequently be safely returned. Immediately upon arriving in Kabul, however, the two brothers got separated from each other. Later, the younger brother, Abolfazi, was allegedly found dead, while Vahid became homeless on the streets of Kabul. Later that year, an independent investigation found that the Danish police had acted wrongly when incarcerating the brothers before their return. Alongside his brother, Abolfazi was therefore granted compensation posthumously (Politiken 12.19.2015). In a Norwegian case, the boy Waziri was deported to Afghanistan, despite the fact that a local court had judged his age to be 16 four days earlier. Yet that decision was overturned by the Norwegian Immigration Appeals Board in the course of just two hours. It found him to be 18 years old - and thus deportable (Klassekampen 8.12.2016).

While the case of the Vazari brothers is uniquely tragic, there are many other examples of arbitrary and wrongful decisions in the Nordic deportation corridors. The credibility argument assumes that the cause of such arbitrariness is the failure of undeportables to comply with return decisions. Moreover, the cost and racist backlash variants also assume that governments are in fact trying to respect or optimize universal protection components of asylum systems. Yet the spread of nationalistic politics in Nordic states raises the question whether Nordic deportation policies are sometimes motivated by ideals other than universal rights and dignity. What we can call the charge of ideology points out that some governments may also be trying to dismantle these components. This turns the prevailing focus on feasibility on its head, since the bigger threat to the credibility of asylum systems may then not stem from undeportables, but from governments' and bureaucracies' rollback of protection ideals. In such cases, while the factual premise that asylum systems face credibility gaps may be true, it will be so for the wrong reason, namely a rollback of rights, checks and balances that contradicts the stated normative ideal of the credibility argument.

To conclude, the original intuition that deportations may be legitimate, since they allow states to enforce differentiation between those who have protection needs and those who do not, remains strong. Yet, observing actual deportation corridors, it is clear that the credibility argument proceeds too quickly when claiming that this 
principled point can override the serious concerns of arbitrariness, tragic enforcement and ideological interference. Even if the credibility argument for deportations is accepted in principle, we might still find actual deportation corridors, their actors, practices and sequence of events so ethically problematic that constraints are placed on the intuition of state discretion. Turning now to the humanitarian argument for deportations, we find that it too faces serious feasibility constraints.

\section{Reassessing the humanitarian argument for deportation}

The variants of humanitarian argumentation are used widely in Nordic and Western asylum politics and exemplify the advent of a "new humanitarianism." According to B.S. Chimni (2000: 255), this means that human rights discourses are placed "in the service of a policy of containment," thereby obscuring how "the Northern commitment to humanitarianism coexists with a range of practices which have for their objective its violation." (Chimni 2000: 251; on "humanitarian border control," see also Fassin 2012; Ticktin 2016). Such co-option poses a serious and general problem for variants of the argument.

But the first variant of the argument, the child's rights claim, also faces the more specific problem that its empirical assumptions about conditions for children in Afghanistan are erroneous. Notably, Nordic efforts to justify the deportation corridor by reference to the rights of the child have intensified at the same time as these conditions have deteriorated massively. Thus, in 2013, Afghanistan hosted a population of 631286 internally displaced persons (IDPs) while 2.6 million refugees remained outside the country (UNHCR 2014). The number of IDPs is the highest in years, reflecting a spread of displacement to new provinces. Assessments of displacement illustrate this as the number of internally displaced persons (IDPs) has risen from 276000 in 2009 to over one million in 2016 (UNHCR 2016). This amounts to dangerous conditions for children, and during 2012 the United Nations Assistance Mission to Afghanistan (UNAMA), reported 1302 casualties among Afghan boys and girls (488 deaths and 814 injured). Of 208 civil incidents with explosive remnants of war (ERW), 160 happened to children carrying out daily activities, and the majority of these casualties occurred from Improvised Explosive Devices (IEDs) and ground engagement between armed forces (UNAMA Statistics 2012). Also, the number of women and girls killed and injured from incidents of drone strikes more than tripled between 2011 and 2012, from 16 to 51 casualties. Illustrating the massive difficulties of creating prospects of development for children, 2012 also witnessed 74 attacks on education facilities, including the burning of schools.

Another risk for children is forced recruitment, often named by UAMs as a prime emigration motivation. For instance, a 17-year old Hazara boy, who fled Afghanistan in 2008, told UNHCR interviewers in Sweden: "The Taliban wanted us to conduct war together with them. We realized there was no way out... it was not only me, but children in my age living in this area. We did not want to join, so after the Taliban had threatened me twice, my father sent me to Iran" (UNHCR 2010: 23). During 2012, a report from The Office of the Special Representative of the Secretary-General for Children and Armed Conflict (2013) noted 66 cases of recruitment, often with multiple victims, including some cases of 8 -year old boys. Children forcibly recruited were used as guards and scouts to carry out attacks and to plant or set off IEDs.

Given these statistics, the child's rights claim unravels quickly, for the actual conditions in Afghanistan turn out to be much worse than even the psychosocial 
limbo for undeportables in the Nordic countries. The many reports about the plight of Afghan children have constituted massive barriers to the construction of UAM deportation corridors to Afghanistan. Ethically speaking, they pose clear structural, political and ethical feasibility constraints on all variants of the credibility and the humanitarian arguments, when these assume deportations to be child friendly.

The second variant of the humanitarian argument is the family unity claim that promises a link between the deportation corridor and family tracing, effectively framing Nordic deportation corridors as family reunification. In a peculiar twist, this variant of the argument then depicts the child's emigration from Afghanistan as an ethical constraint on the same child's right to family unity. In so doing, this claim effectively subordinates the child's independence under an identity as part of a family. This denial of the child as an individual rights holder in the ERPUM discourses is a recurring practice in Nordic asylum authorities (cf. Stern 2015; Josefsson 2016), which exhibit a tendency to disregard UAMs' voice and agency about their own futures and the structural barriers they face (Hedlund and Cederborg 2015; Keselman, Cederborg, and Linell 2010).

As noted above, the multiple threats to children and civilians in Afghanistan also problematize this claim, as does the fact that many UAMs and their families have not lived in the country for years, having instead been displaced to Iran and Pakistan (cf. Schuster and Majidi 2015). In recent years, these two countries have begun to conduct massive deportation sweeps back to Afghanistan citing "protection fatigue." In 2016, according to the Afghan Ministry of Refugees and Repatriation (MoRR), an estimated one million people were forcibly returned to Afghanistan. More than 410000 people returned from Iran between July and December 2016, and around 253000 refugees were forcibly returned from Pakistan during the same year. This has led to an even more volatile and tumultuous situation for displaced Afghanis in all three countries (Majidi 2017: 4, 8-9). As we shall see next, this does not bode well for the optimistic visions that tracing can turn UAM deportations into tools of family reunification.

Conditions in Afghanistan have problematized family tracing for a long time. Indeed, ERPUM's optimism was hard to comprehend given the history of Northern European family tracing in the decade before the project's launch in 2011. In 2006 the Norwegian Immigration Service, UDI, commissioned a report to gain an overview of European attempts to trace the families of UAMs (Danielsen and Seeberg 2006). It compared the tracing experiences of nine European countries and showed that no countries had developed successful tracing methods. The report also revealed the existence of very different practices of data collection: Finland had launched a tracing project in 2006, but was unable to provide any information about its success rate; Denmark had no successful examples of family tracing after 2003. Even when authorities claimed success, they were unable to give exact numbers. Between 2001 and 2005, the Norwegian UDI claimed to have traced family members of "either 10 or 12" UAMs, and to have returned "between one and five" UAMs to families or caretakers. And Swedish authorities were unable to tell exactly how many tracings had been initiated in 2006, settling on a number "between 10 and 15" (Danielsen and Seeberg 2006: 26-39). The report showed numerous difficulties with family tracing in war-torn countries, such as insecurity, fragmented infrastructures, corrupt authorities, internal displacement and population movement and contexts of emigration and re-migration. The report also highlighted an absence of best practices of tracing and for independent post-deportation monitoring. 
ERPUM was proud to announce tracing workshops in Stockholm, London, Utrecht and Oslo during 2013 and 2014, but the same difficulties quickly and predictably resurfaced, as the Afghan security situation had continued to deteriorate, adding further strain to postal and communications networks. This effectively left the ERPUM governments' embassies as the only viable tracing options, but failing resources and logistics hampered their activities. Initially, at the beginning of the project, ERPUM placed high hopes on collaborating with the International Organization for Migration (IOM), but the organization quickly expressed serious reservations concerning the lack of child-specific safeguards (Lemberg-Pedersen 2015). In 2013, the organization withdrew from ERPUM altogether. In January 2014, the local tracing staff under the Identity Checking Unit (IDCU) did the same, citing security reasons. In its final report before the project was discontinued, ERPUM characterized its own tracing efforts as "reasonably successful." Yet, the fact remains that only 34 out of 148 Afghan families were eventually traced and no children were returned to their families. Of the 34 cases, one family was deceased, while 14 families had their identity confirmed but could not be located. In 75 cases, the tracing efforts yielded no results whatsoever (ERPUM 2014: 41).

The case of ERPUM's failed family tracing illustrates that the humanitarian argument for deportation faces devastating structural/institutional and political feasibility constraints. Even if we, for the sake of argument, assume that deportations were intended to promote family unity, the argument is undermined by the reality of family tracing in conflict-ridden or otherwise collapsing societal contexts, such as Afghanistan. Still, arguments based on the ideal of family reunification continue to dominate Nordic deportation politics. One reason for this could be that this narrative is linked to a culturalist thesis concerning the value of national belonging, thus portraying deportation as a return "home" to the national cultural family. The notion of return is thus derived from idealized assumptions, which understand communities and social life from within a national order of things (Malkki 1995). Deportation corridors are thus seen as processes of national resituation and as with the claim of family unity, this nationalistic argument also subsumes the rights of the individual to that of the larger, now national, family. Evidently, the resituation thesis aligns strongly with key points of nationalistic ethics. Next, we consider what such a normative outlook means for the connection between authorities' feasibility claims and their own motivations.

\section{Benevolent deterrence and the kidnapper's argument}

The third and last variant of the humanitarian argument, that of benevolent deterrence, claimed that the existence of deportation corridors will make child migrants choose not to come to Europe. This logic is mirrored by the early ERPUM discourses, in which the project's 2010 grant proposal to the European Commission, authored by the Swedish Migration Agency, focused on the goal of a "lowering influx of unaccompanied minors to Europe." This was seen as achievable because "those minors who are not in need of protection will not make the long and risky journey to Europe since the risk of being returned is higher." (ERPUM 2010: 13-15). The project was in fact conceived of as a UAM deterrence tool, illustrating that despite the humanitarian arguments made, ERPUM was always intended as a "return platform" and not a "child protection platform" (Lemberg-Pedersen 2015). Its entire focus revolved around deportation, and the project exhibited no interest in other crucial 
issues, like the emotional impact of flight trauma and anxiety for UAMs, or of their attempts to make sense of home and belonging in Nordic contexts characterized by processes of social exclusion (Wernesjö 2015). Furthermore, the deterrence rationale also reveals the existence of fundamental feasibility constraints facing this kind of humanitarian argumentation.

Some of the reasons for the trauma of UAM undeportables may seem unavoidable, because they have to do with the very nature of irregular escape from violent conflict zones, separation from family and the uncertainty in asylum systems. However, other reasons for trauma are not unavoidable, and across the Nordic countries, political actors have justified several such conditions for deportables with reference to deterrence logic. This means that some of the assumptions invoked by the humanitarian argument should be considered contestable feasibility claims.

We can invoke two conceptual distinctions to better understand this. The first distinguishes between subjective and objective feasibility claims (Cohen 1992). Subjective claims denote situations when an ideal that lacks realism depends on the intentions of moral agents, while objective claims encompass situations where the lack of realism is caused by factors beyond their control. What this tells us is that we need to ask for the reasons why an ideal is infeasible, and whether these have to do with the lack of will of those implementing it. Cohen (1992: 278) has pointed out that subjective claims of strong ethical constraints on ideals can work like a kidnapper's argument, in the context of the humanitarian argument, means that critics can argue that the psychosocial trauma of undeportable children is actually not an objective feasibility constraint on the ideal of UAM rights and dignity. Rather, it is a subjective constraint, because the children's traumatizing conditions result from states' intentions to deter future arrivals by lowering the living standards of undeportables and speed up their removal.

The second conceptual distinction is between strong and weak feasibility constraints (Lægaard 2008). Strong constraints make ideals impossible to implement or uphold, and are thus akin to Cohen's notion of objective constraints, while weak constraints mean that ideals may be morally costly to implement. This notion of moral costs is then similar to Gibney's ethical constraints, as it also implies the weighing of normative ideals against the ethical side effects of their own implementation. For instance, the ideal of family and national reunification exemplify a nationalistic ideal facing strong structural and political feasibility constraints, because tracing and deportation is often not possible in war-torn countries ravaged by massive internal displacement. When it comes to weak feasibility constraints, an example would be the political decision to implement and uphold a non-arbitrary asylum system, because its moral value outweighs its side effects, such as the creation of undeportables and racist backlash.

When politicians or governments depict controversial policy choices as predetermined by strong feasibility constraints, it is crucial to pay attention to how such claims assume certain motivational and empirical preconditions (Lægaard 2006). And in the case of ERPUM, the benevolent deterrence claim withers away when one realizes that the psychosocial consequences of the deportation corridor are not a necessary background condition, but in fact result from governments' choices to use detrimental humanitarian conditions to induce people to leave and deter others from arriving. 


\section{Conclusion}

This article has examined Nordic "deportation corridors" through a case study of the European Return Platform for Unaccompanied Minors (ERPUM), which Sweden, Denmark and Norway participated in from 2011 to 2014. The notion of feasibility constraints was used to critically assess the realism and idealism of deportations, a perspective currently overlooked in the emerging field of deportation studies. Also, departing from most discussions in immigration ethics, this article examined feasibility constraints not as realistic barriers to the lofty ideals of cosmopolitan open borders, but instead turned this perspective on its head, and discussed structural/institutional, political and ethical feasibility constraints on nationalistic arguments for the deportation of unaccompanied minors to Afghanistan.

Two main arguments for deportation were introduced, labeled the credibility and the humanitarian arguments. The credibility argument rested on the powerful, principled intuition that asylum systems must be capable of using deportation to enforce the line between those who are in need of protection and those who are not. Its variants included feasibility claims about costs and the risk of racist backlash. Yet, observation of the actual enforcement of deportation corridors opened the argument to charges of arbitrariness and ideology. The charge of arbitrariness shows that even if we grant that states' discretion over their borders is legitimate, the credibility argument can be insufficient to override the rights and dignity of deportation targets in concrete cases. And the charge of ideology further revealed that the argument's empirical premise of a lack of credibility might be right for the wrong reasons. If the premise is actually caused by states' nationalistic rollback of asylum seekers' universal rights, that would contradict the argument's own normative premise of protection.

Like the credibility argument, the humanitarian argument advanced a mix of feasibility constraints, expressed in variants concerning the rights of the child, family unity and benevolent deterrence, all of which were identified in ERPUM discourses. However, appeals to "new humanitarianism" quickly encountered massive feasibility challenges of their own due to conditions in Afghanistan. The dangerous and deteriorating conditions for children and civilians in general in Afghanistan includes risks of forced recruitment, improvised explosive devices (IEDs) and drone strikes. In a similar manner, the Afghan context of internal and external displacement, and Iranian and Pakistani mass deportations, illustrated that the many ERPUM workshops that promised family tracing were a politically convenient mirages without any foothold in reality. The continuing emphasis on reunification is also connected to an ideal of resituating the child into the national family, which, much like the ERPUM's framing of its deportation corridor as a tool for family reunification, bypasses the child as an independent rights holder. A core problem facing both the credibility and humanitarian arguments is their depiction of subjective feasibility claims, which rely on actors' intentions and political will, as a strong and objective feasibility constraint on what is politically and ethically possible. And in cases where the justifying reasons for the terrible conditions of undeportables are actually found in the partial compliance and lack of will of the deporting actors themselves, a logic similar to a "kidnapper's argument" is evident.

In Miller's view, feasibility constraints concerning the (lack of) political and popular support for ideals can be resolved through reasoned discussion and deliberation. But surely, this grants reason too much primacy and omits how ideology may not only influence our view on norms, but also of facts. As Joseph Carens stated 
(1999: 1086): “...it is probably fair to say that people sometimes disagree about what the real world is as much as (if not more than) they disagree about what a just world would look like." Similarly, discussions about Nordic deportation politics reflect divisions not merely over policies and their normative values, but also ideological ones spanning complex structural/institutional, political and juridical contexts.

Given the intensity of ideological divisions, it is problematic that Miller and nationalistic ethics present his substantive ethical conclusions about border controls "as if they issue relatively unproblematically from the encounter between people's everyday moral judgments and the philosopher's 'due reflection' process." (Bosniak 2017: 8). Rather, the actual evolution of Nordic deportation politics - through controversies, fierce debates and anti-deportation campaigns - demonstrates that "our normative contexts are...riven scenes of self-wrestling and embattlement" (Bosniak 2017: 8). Miller claims that his contextualism is pluralistic because it can say something substantial about normative pluralism between contexts. Yet, characteristic of the homogenizing move of nationalistic ideology, his contextualism appears silent when it comes to normative discordance within national contexts. Miller's assumption that rational deliberation will be able to settle such disagreements therefore repeats the overestimation of reason that he himself accuses cosmopolitans of. At the same time, it grossly underestimates how powerful ideology is in shaping people's world views.

The combination of ideological struggles and the multiple feasibility constraints facing the two arguments for deportation constitutes a powerful critique of nationalistic deportation ethics in general, and of the attempts to construct deportation corridors for unaccompanied Afghan minors in particular. And so, while concerns about the feasibility of cosmopolitan immigration ethics are legitimate, cosmopolitanism is not the only view that has to face up to reality. For too long, nationalistic idealism and politics have not been asked to confront this kind of criticism, illustrated by the fact that, while David Miller has a lot to say about the principled legitimacy of border control, he says nothing about the enforcement of deportations towards vulnerable groups like unaccompanied minors (Bosniak 2017: $11)$.

At the end of the day, Miller's critique of cosmopolitanism relied on the everyday, pre-theoretical and motivational power of ordinary citizens that he assumes to be the strength of nationalistic theories. However, it is not clear that motivational power is exclusive to nationalistic ethics. Even putting aside Cohen's worry that meta-ethical fact dependency allows biases to delimit normative ideals, Miller's view, by any measure, must grant feasibility crucial weight.

But motivation is but one possible feasibility constraint on normative ideals. As Gibney points out, other crucial constraints turn on whether arguments' empirical assumptions correspond to the structural, political and ethical contexts where ideals are to be implemented. The case of ERPUM shows that nationalistic deportation ethics can fare poorly against such constraints. For all its emphasis on facts, nationalistic ethics seems to disregard crucial questions concerning institutional/structural and political ethical feasibility. It thereby leaves the issue of implementation underdetermined and seems to end up with the implausible view that the feasibility of ideals dictating UAM deportations need only be justified by referring to the pre-theoretical opinions and motivations of Nordic citizens, and not by any reference to the actual causes, choices, conditions and hazards of children in 
Nordic deportation corridors or Afghanistan. Considering that nationalistic ethics is brandished as factually based, and that it criticizes cosmopolitanism of lofty abstractions, this is a damning critique. The arguments for the ongoing Nordic attempts to build UAM deportation corridors to Afghanistan seem to amount to "fact-independent theorizing" that are based on some "imaginary world whose natural and social laws are different" from reality.

\section{Acknowledgments}

For comments on earlier versions of this article, the author would like to thank the participants in the NOS-NH workshop in Tromsø: Sune Lægaard, Nils Holtug, Mine Islar, Barak Kalir and two anonymous reviewers.

\section{Notes}

${ }^{1}$ It has been argued that Miller's and Rawls' meta-ethical position conflates what is actually a distinction between basic principles and principles of regulation. Here, the former are normative ideals we choose to strive for, and the latter are the "devices for having certain effects" best suited to implement those ideals (Cohen 2003: 241). Only the latter takes into account feasibility concerns other than those concerned with motivation. Cohen's point is to avoid letting status quo biases determine the formulation of principles of justice, and it can be argued that this is exactly what happens when Miller allows the "sedentary bias" (Bakewell 2008) of nationalism to grant ethical priority to national compatriots over outsiders (Cole 2000).

\section{References}

Abizadeh, A. (2010). Democratic Legitimacy and State Coercion: A Reply to David Miller. Political Theory, 38(1): 121-130. https://doi.org/10.1177/0090591709348192

Abizadeh, A. (2008). Democratic Theory and Border Coercion: No Right to Unilaterally Control Your Own Borders. Political Theory, 36(1): 37-65. https://doi.org/10.1177/0090591707310090

Bakewell, O. (2008). "Keeping them in Their Place": the ambivalent relationship between development and migration in Africa. Third World Quarterly 29(7): 13411358.

Barry, B. and Goodin, R.E. (eds) (1992). Free Movement. Ethical Issues in the transnational migration of people and money. London: Harvester Wheatsheaf.

Beitz, C. (1983). Cosmopolitan Ideals and National Sentiments. The Journal of Philosophy, 80(10) (October 1983): 591-600. https://doi.org/10.2307/2026155

Benhabib, S. (2006). Another Cosmopolitanism. The Berkeley Tanner Lectures. New York: Oxford University Press. https:/doi.org/10.1093/acprof:oso/ 9780195183221.001.0001

Borhan, C., Paulsen, V., Valenta, M., Grossmann, G., Dirdal, K. (2011). Livsmestring hos enslige mindreårige asylsøkere. Utprøving av HIPP-metoden i returmotiverende arbeid i mottak. NTNU Samfunndsforskning AS. Trondheim. 
Bosniak, L. (2017). Immigration Ethics and the Context of Justice. Ethics and International Affairs, 31(1), Spring 2017: 93-102. https://doi.org/10.1017/ S089267941600068X

Brown, P.G. and Shue, H. (1981). Boundaries, national autonomy and its limits. Rowman and Littlefield.

Carens, J. (2013). The Ethics of Immigration Policy. Oxford: Oxford University Press.

Carens, J. (1999). A Reply to Meilaender: Reconsidering Open Borders. International Migration Review, 33(4) (Winter, 1999): 1082-1097. https://doi.org/10.2307/ 2547364

Carens, J. (1987). Aliens and Citizens: The Case for Open Borders. The Review of Politics, 49(2): 251-73. https://doi.org/10.1017/S0034670500033817

Chase, E., Allsopp, J. and Mitchell, M. (2014). The Tactics of Time and Status: Young People's Experiences of Building Futures While Subject to Immigration Control in Britain. Journal of Refugee Studies, vol. 28, no.2: 163-182.

Chimni, B.S. (2000). Globalization, Humanitarianism and the Erosion of Refugee Protection. Journal of Refugee Studies, Vol.13, No. 3: 243-263. https://doi.org/ 10.1093/jrs/13.3.243

Chimni, B.S. (1999). From Resettlement to Involuntary Repatriation: Towards a Critical History of Durable Solutions to Refugee Problems. UNHCR Working Paper No. 2, Geneva: Centre for Documentation and Research.

Cole, P. (2000). Philosophies of Exclusion: Liberal Political Theory and Immigration. Edinburgh: Edinburgh University Press.

Cohen, G.A. (2003). Facts and Principles. Philosophy \& Public Affairs, 31(3): 211-245. https://doi.org/10.1111/j.1088-4963.2003.00211.x

Cohen G.A. (1992). Incentives, inequality and community. In: Peterson G (ed.) The Tanner lectures on human values, vol. 13. University of Utah Press, Salt Lake City: 263-329.

Cohen, R. (1997). Shaping the nation, excluding the other: the deportation of migrants from Britain. Lucassen, J. and Lucassen, L. (eds.) Migration, migration history, history: Old paradigms and new perspectives. International and comparative social history 4. Bern, Switzerland: Peter Land.

Danielsen, K. and Seeberg, M.L. (2006). Tracing UMAs' families. A comparative study of some European countries' practice and experiences in tracing the parents or caregivers of unaccompanied minor asylum seekers. Norwegian Social Research. NOVA Rapport 19/2006. https://doi.org/10.7577/nova/rapporter/2006/19

Danish Government Platform. (27.11.2016). En balanceret og realistisk udlondingepolitik. Retrieved March 15, 2018 from: https://www.regeringen.dk/regeringsgrundlag/

DeBono, D. (2017). 'Burning without fire' in Sweden: the paradox of the state's attempt to safeguard deportees' psychosocial wellbeing. Vathi, Z. \& King, R. (eds.) Return Migration and Psychosocial Wellbeing: Discourses, Policy-Making and Outcomes for Migrants and their Families. London: Routledge.

Drotbohm, H., and I. Hasselberg. (2015). Editorial Introduction to Deportation, Anxiety, Justice: New Ethnographic Perspectives. Journal of Ethnic and Migration Studies, 41(4): 551-562. https://doi.org/10.1080/1369183X.2014.957171

ERPUM. (2014). Separation - Reunification. Four countries cooperating on family tracing and return of unaccompanied minors. Swedish Migration Agency. 
ERPUM. (2010). Grant Application to the European Return Fund, European Commission, Directorate-General Justice, Freedom, Security.

EU/Afghanistan. (2.10.2016). Joint Way Forward on migration issues between Afghanistan and the EU. European External Action Service. Retrieved March 15, 2018 from: https://eeas.europa.eu/sites/eeas/files/eu_afghanistan_joint_way _forward_on_migration_issues.pdf

Fassin, D. (2012). Humanitarian Reason. A Moral History of the Present. Gomm, R. (transl.) Berkeley: University of California Press.

Fekete, L. (2011). Accelerated removals: the human cost of EU deportation policies. Race \& Class 52(4): 89-97. https://doi.org/10.1177/0306396810396605

Fekete, L. (2005). The deportation machine: Europe, asylum and human rights. Race \& Class, 47(1): 64-91. https://doi.org/10.1177/0306396805055083

Gibney, M. (2015). Political Theory, Ethics and Forced Migration. FiddianQasmiyeh, Loescher, Long and Sigona (eds.) The Oxford Handbook of Refugee and Forced Migration Studies. Oxford: Oxford University Press.

Gibney, M. (2013). Is Deportation a Form of Forced Migration? Refugee Survey Quarterly, Vol.32, No. 2: 116-129. https://doi.org/10.1093/rsq/hdt003

Gibney, M. (2008). Asylum and the Expansion of De Deportation in the United Kingdom. Government and Opposition, 43(2): 146-167. https://doi.org/10.1111/ j.1477-7053.2007.00249.x

Gibney, M. (2004). The Ethics and Politics of Asylum: Liberal Democracy and the Response to Refugees. Cambridge: Cambridge University Press. https://doi.org/ 10.1017/CBO9780511490248

Hedlund, D. and Cederborg, A.-C. (2015). 'Legislators' perceptions of unaccompanied children seeking asylum. International Journal of Migration, Health and Social Care, 11(4) 239-252. https://doi.org/10.1108/IJMHSC-08-20140033

Holtug, N. (2011). The Ethics of Immigration Policy. Nordic Journal of Migration Research, 1(1): 4-12. https://doi.org/10.2478/v10202-011-0002-4

Islar, M., Brogaard, S. and Lemberg-Pedersen, M. (2017). Feasibility of energy justice: Exploring national and local efforts for energy development in Nepal. Energy Policy 105 (supplement C): 668-676. https://doi.org/10.1016/j.enpol.2017.03.004

Johannesson, L. (2017). In Courts We Trust. Administrative Justice in Swedish Migration Courts. Ph.D. Dissertation. Stockholm: Stockholm University.

Josefsson, J. (2017). 'We beg you, let them stay!': Right claims of asylum-seeking children as a socio-political practice. Childhood, 24(3): 316-322. https://doi.org/ $10.1177 / 0907568216674785$

Josefsson, J. (2016). Children's Rights to asylum in the Swedish Migration Court of Appeal. International Journal of Children's Rights. 25(1): 85-113. https://doi.org/ 10.1163/15718182-02501009

Keselman, O., Cederborg, A.-C., and Linell, P. (2010). 'That is not necessary for you to know!' Negotiation of participation status of unaccompanied children in interpreter-mediated asylum hearings. Interpreting 12(1): 83-104. https://doi.org/ 10.1075/intp.12.1.04kes

Khosravi, S. (2018). After Deportation. Ethnographic Perspectives. Palgrave Macmillan. https://doi.org/10.1007/978-3-319-57267-3.

Klassekampen. (8.12.2016). I strid med returavtale. Retrieved May 17, 2018 from: http://www.klassekampen.no/article/20161208/PLUSS/161209829 
Larmore, C. (2003). Liberal and republican conceptions of freedom. Critical Review of International Social and Political Philosophy, 6(1): 96-119. https://doi.org/ 10.1080/13698230510001702693

Lemberg-Pedersen, M. (2018). Security, Industry and Migration in European Border Control. Weinar, A., Bonjour, S. and Zhyznomirska, L. (eds.) The Routledge Handbook of the Politics of Migration in Europe. Routledge.

Lemberg-Pedersen, M. and Chatty, D. (2015). ERPUM and the Drive to Deport Unaccompanied Minors. Refugee Studies Centre, Research in Brief, 4, Oxford.

Lemberg-Pedersen, M. (2015). The Rise and Fall of the ERPUM pilot. Tracing the European policy drive to deport unaccompanied minors. Refugee Studies Centre, Working Paper 108. Oxford.

Lemberg-Pedersen, M. (2013). The evolution of the ERPUM project. LembergPedersen et. al. The deportation of unaccompanied minors from the EU. Family tracing and government accountability in the European Return Platform for Unaccompanied Minors (ERPUM) project. Conference Report, Refugee Studies Centre.

Lemberg-Pedersen, M. (2011). "Værdier, interesser og praksisser i asylpolitiske tiltag over for børn" in Vitus, K. and Smith Nielsen, S. Asylbørn I Danmark: En barndom $i$ undtagelsestilstand. Hans Reitzels Forlag, København: 211-229.

Lenard, P.T. (2015). The ethics of deportation in liberal democratic states. European Journal of Political Theory, 14(4): 464-480. https://doi.org/10.1177/ 1474885115584834

Lier, L., Jansson, P. and Rich, B. (2011). Asylbørns psykiske lidelser. Vitus, K. and Smith Nielsen, S. (eds.) Asylbørn i Danmark: En barndom i undtagelsestilstand. Copenhagen: Hans Reitzels Forlag.

Lægaard, S. (2016). Contextualism in Normative Political Theory. Oxford research Encyclopedia of Politics. https://doi.org/10.1093/acrefore/9780190228637.013.87

Lægaard, S. (2010). What is the right to exclude immigrants? Res Publica, 16(3): 245262. https://doi.org/10.1007/s11158-010-9122-2

Lægaard, S. (2006). Feasibility and Stability in Normative Political Philosophy: The Case of Liberal Nationalism. Ethics, Theory, Morality, Practice, 9: 399-416. https://doi.org/10.1007/s10677-006-9048-0

Malkki, L. (1995). Refugees and Exile: From "Refugee Studies" to the National Order of Things. Annual Review of Anthropology, 24: 495-523. https://doi.org/10.1146/ annurev.an.24.100195.002431

Majidi, N. (2017). From Forced Migration to Forced Returns in Afghanistan: Policy and Program Implications. Transatlantic Council on Migration.

Miller, D. (2016). Strangers in Our Midst: The Political Philosophy of Immigration. Harvard: Harvard University Press. https://doi.org/10.4159/9780674969827

Miller, D. (2013). Justice for Earthlings: Essays in Political Philosophy. Cambridge University Press.

Miller, D. (2010). Why Immigration Controls are Not Coercive: A Reply to Arash Abizadeh. Political Theory, 38(1): 111-120. https://doi.org/10.1177/ 0090591709348194

Miller, D. (2007). National Responsibility and Global Justice. Oxford: Oxford University Press, 2007. https://doi.org/10.1093/acprof:oso/9780199235056.001.0001

Miller, D. (2005). Reasonable partiality towards compatriots. Ethical theory and moral practice, 8(1) 2005: 63-81. 
Miller, D. (2002). Two ways to think about justice. Politics, philosophy \& economics 1(1): 5-28. https://doi.org/10.1177/1470594X02001001001

Miller, D. (1995). On nationality. Clarendon Press, 1995.

Montgomery, E. (2011). "Langtidsfølger." Vitus, K. and Smith Nielsen, S. (eds.) Asylbørn i Danmark: En barndom $i$ undtagelsestilstand. Copenhagen: Hans Reitzels Forlag.

New York Times. (12.11.2016). A Deported Afghan Boy Returns to a Land Nothing Like Home. Retrieved May 17, 2018 from: https://www.nytimes.com/2016/11/13/ world/asia/a-deported-afghan-boy-returns-to-a-land-nothing-like-home.html

Noll, G. (2016). Junk Science? Four Arguments against the Radiological Age Assessment of Unaccompanied Minors Seeking Asylum. International Journal of Refugee Law, 28(2): 234-250. https://doi.org/10.1093/ijrl/eew020

Pallister-Wilkins, P. (2015). 'The Humanitarian Politics of European Border Policing: Frontex and Border Police in Evros.' In International Political Sociology, Vol. 9: 53-69. https://doi.org/10.1111/ips.12076

Pevnick, R. (2011). Immigration and Constraints of Justice: Between Open Borders and Absolute Sovereignty. Cambridge: Cambridge University Press. https://doi.org/ 10.1017/CBO9780511975134

Plambech, S. (2017). Sex, Deportation and Rescue: Economies of Migration among Nigerian Sex Workers. Feminist Economics, 23(3): 134-159. https://doi.org/ 10.1080/13545701.2016.1181272

Politiken. (12.10.2015). Politifejl: Frihedsberøvelse af afghanske brødre var uberettiget. Retrieved March 15, 2018 from: https://politiken.dk/indland/art5593442/ Politifejl-Frihedsber\%C3\%B8velse-af-afghanske-br\%C3\%B8dre-var-uberettiget

Rawls, J. (1999). The Law of Peoples with "The Idea of Public Reason Revisited." Cambridge, MA: Harvard University Press.

Rawls, J. (1996). Justice as fairness: a restatement. Cambridge, MA: Harvard University Press.

Refugees.dk. (13.11.2015). Afghanere og irakere får oftere afslag på asyl i Danmark. Retrieved March 15, 2018 from: http://refugees.dk/fokus/2015/november/ afghanere-og-irakere-faar-oftere-afslag-i-danmark/

Sager, A. (2017). Immigration Enforcement and Domination. An Indirect Argument for Much More Open Borders. Political Research Quarterly, 70(1): 42-54. https://doi.org/10.1177/1065912916680036

Sass Larsen, H. 2017. Hos $S$ tager vi befolkningens modstand mod masseindvandring alvorligt. Retrieved March 15, 2018 from https://www.information.dk/debat/2017/ 03/s-tager-befolkningens-modstand-masseindvandring-alvorligt?lst_dbt

Schuster, L., and Majidi, N. (2015). Deportation Stigma and Re-migration. Journal of Ethnic and Migration Studies, vol. 41, no. 4: 635-652. https://doi.org/10.1080/ 1369183X.2014.957174

Seglem, K.B., Oppedal, B. and Raeder, S. (2011). Predictors of depressive symptoms among resettled unaccompanied refugee minors. Scandinavian Journal of Psychology 2011, 52: 457-64. https://doi.org/10.1111/j.1467-9450.2011.00883.x

Stern, R. T. (2015). Unaccompanied and Separated Asylum-seeking Minors: Implementing a Rights-based Approach in the Asylum Process. Mahmoudi, S., Leviner, P., Kaldal, A. and Lainpelto, K. (eds.) Child-friendly Justice. A Quarter of a Century of the UN Convention on the Rights of the Child: 242-255. 
Stretmo, L. (2014). Governing the unaccompanied child - media, policy and practice. Göteborgs studies in Sociology No.56. Department of Sociology and Work Science, University of Gothenburg.

Svendsen, L. F. (2012). Papirløses rett til å søke arbeid. En konsekvensetisk vurdering. Nordic Journal of Applied Ethics, 6(2): 38-45. https://doi.org/10.5324/eip.v6i2.1783

The Office of the Special Representative of the Secretary-General for Children and Armed Conflict (2013). Retrieved March 15, 2018 from: http://childrenandarmedconflict.un.org/countries/afghanistan/.

Ticktin, M. (2016). Thinking Beyond Humanitarian Borders. Social Research: An International Quarterly, 83(2): 255-271.

UNAMA Statistics (2012). Retrieved March 15, 2018 from: http://unama.unmissions.org/LinkClick.aspx?fileticket=K0B5RL2XYcU\%3D

UNHCR website (2016). Retrieved March 15, 2018 from: http://unhcr.org

UNHCR. (2014). Regional Refugee Statistics, December 2012-1 June 2014. UNHCR.

UNHCR (2010) Voices of Afghan Children - A Study on asylum-seeking children in Sweden. Retrieved March 15, 2018 from: http://www.unhcr.org/4c8e24a16.html.

Verdasco M.A. (2017). Understandings of self through the category of the 'unaccompanied asylum-seeking minor': a Danish ethnography. Barn, no. 2-3: 4357.

Vitus, K. (2010). Waiting time. The de-subjectification of children in Danish asylum centres. Childhood 17(1): 26-42. https://doi.org/10.1177/0907568209351549

VG Nyheter (10.5.2010). Stoltenberg vil kaste flere ut av landet. Retrieved March 15, 2018 from: https://www.vg.no/nyheter/innenriks/arbeiderpartiet/stoltenberg-vilkaste-flere-ut-av-landet/a/10005254/

Walters, W. (2017). Aviation as deportation infrastructure: airports, planes and expulsion. Journal of Ethnic and Migration Studies. https://doi.org/ 10.1080/1369183X.2017.1401517

Walters, W. (2011). Foucault and frontiers: Notes on the birth of the humanitarian border. In (eds.) Bröckling, U., Krasmann, S., and Lemke, T. Governmentality: Current issues and future challenges. New York, NY: Routledge: 138-164.

Walzer, M. (1983). Spheres of Justice: A Defense of Pluralism and Equality. Basic Books: New York.

Wernesjö, U. (2015). Landing in a rural village: home and belonging from the perspectives of unaccompanied young refugees. Identities. Global Studies in Culture and Power, 22(4): 451-467. https://doi.org/10.1080/1070289X.2014.962028

Wettergren, $\AA$. and Wikström, H. (2013). Who Is a Refugee? Political Subjectivity and the Categorisation of Somali Asylum Seekers in Sweden. Journal of Ethnic and Migration Studies, 20(4): 566-583. https://doi.org/10.1080/1369183X.2013.830502

Wiens, D. (2014). "Going evaluative" to save justice from feasibility: A pyrrhic victory. Philosophical Quarterly 64: 301-307. https://doi.org/10.1093/pq/pqt057 